\title{
Genetic Diversity of a Brazilian Strain Collection of Xanthomonas citri subsp. citri Based on the Type III Effector Protein Genes
}

F. J. Jaciani, J. A. Ferro, and M. I. T. Ferro, Faculdade de Ciências Agrárias e Veterinárias, UNESP - Univ. Estadual Paulista, Campus de Jaboticabal, Departamento de Tecnologia, Jaboticabal, SP, Brazil; C. Vernière, and O. Pruvost, CIRAD, UMR Peuplements Végétaux et Bioagresseurs en Milieu Tropical CIRAD-Université de la Réunion, Pôle de Protection des Plantes, 7, chemin de l'Irat, 97410 Saint Pierre, Réunion, France; and J. Belasque Jr., Fundo de Defesa da Citricultura, Araraquara, SP, Brazil

\begin{abstract}
Jaciani, F. J., Ferro, J. A., Ferro, M. I. T., Vernière, C., Pruvost, O., and Belasque, J., Jr. 2012. Genetic diversity of a Brazilian strain collection of Xanthomonas citri subsp. citri based on the type III effector protein genes. Plant Dis. 96:193-203.

Exclusion and eradication or management based on an integrated approach with less susceptible varieties, copper-based bactericides, and windbreaks are the two main strategies used to prevent or control citrus canker. Field tolerance or resistance to citrus canker is not found in the most important commercial sweet orange cultivars, and pathogenderived resistance has been developed and applied in different crops to obtain resistant genotypes to plant pathogens. We describe the development of DNA primers and probes based on the type III effector genes avrXacE1, avrXacE2, avrXacE3, avrBs2, pthA4, hpaF, and XAC3090 (leucine rich protein), and their application in the evaluation of the genetic diversity of the pathogen. A total of 49 haplotypes were identified in 157 strains by Southern blot analysis. No genetic polymorphism was detected by BOX elements - and enterobacterial repetitive intergenic consensus-polymerase chain reaction (ERIC-PCR) analysis, nor

with the genes avrBs2, XAC3090, and hpaF. Nei's genetic diversity indexes varied from 0.65 to 0.96 for subcollections of the pathogen. One or few haplotypes were most frequent in the strain collection, but several haplotypes were represented by solely one or few strains. The PthA4 probe resulted in the higher number of haplotypes identified in the Brazilian subcollections. Greater variation in the frequency of haplotypes occurred within subcollections (93.7\%) than among subcollections. Only some haplotypes were genetically distant from all others, especially those originated from Rio Grande do Sul and Santa Catarina states. These bacterial effectors are widely spread in the collections and are useful for a better understanding of the hostpathogen interaction and the search for resistance genes in host and nonhost plants.
\end{abstract}

The genus Xanthomonas includes a group of phytopathogenic bacteria that have great economic importance around the world. The classification of species of Xanthomonas pathogenic to citrus has been modified in the last decades $(21,41,42,45,46)$. The most recent reclassification is based on analysis of the $16 \mathrm{~S}-23 \mathrm{~S}$ intergenic spacer region, amplified fragment length polymorphism (AFLP), phenotypic characteristics, and DNA-DNA reassociation assays (42). Based on that, the citrus canker-causing xanthomonads have been classified in two species: Xanthomonas citri subsp. citri and $X$. fuscans subsp. aurantifolii. However, Ah-You et al. (3) suggested that $X$. fuscans is a later heterotypic synonym of $X$. citri (ex Hasse 1915) (21). X. fuscans subsp. aurantifolii is the causal agent of South American canker, which is regarded as a mild pathogen of citrus and represents the pathotypes B and C. Recently, a new strain of the aurantifolii $\mathrm{C}$ type was detected in São Paulo State in Brazil infecting 'Swingle' citrumelo (C. paradisi $\times$ Poncirus trifoliata) (28). X. citri subsp. citri is the causal agent of Asiatic canker, a major citrus pathogen worldwide. This pathogen has been separated into three pathotypes differing in host range, aggressiveness, and geographic origin. Strains with a wide host range within the genus Citrus and relatives have been described as pathotype A and are present in citrus producing areas in Asia and North and South America (24). Two other pathotypes with a pathogenicity restricted to acid lime (C. aurantifolia) under field conditions have been described in Asia and Florida and are designated as $A^{*}(48)$ and $A^{\mathrm{w}}$ (43), respectively. A different citrus disease affect-

Corresponding author: J. Belasque Jr.,

E-mail: belasque@fundecitrus.com.br

Accepted for publication 2 August 2011.

http://dx.doi.org/10.1094/PDIS-04-11-0357

(C) 2012 The American Phytopathological Society ing exclusively 'Swingle' citrumelo only reported in Florida until now, known as citrus bacterial spot, is caused by $X$. alfalfae subsp. citrumelonis $(23,42)$.

Citrus canker is one of the most important diseases of citrus worldwide and is present in the main citrus-producing areas - São Paulo and Florida $(24,25)$. Currently, São Paulo, which represents $53 \%$ of the total world production of orange juice, is the only region where citrus canker eradication is still practiced in Brazil $(11,12)$. Exclusion and eradication are the main strategies used to prevent and control citrus canker in nonendemic areas (24). Management of citrus canker on sweet oranges based on an integrated approach with less susceptible varieties, spray of copper-based bactericides, and windbreaks, is a sustainable alternative to eradication in areas where the causal agent has widely established or has become endemic, and is being practiced in Southern Brazil (8$10)$.

Theoretically, the best control strategy for bacterial diseases affecting plants, such as citrus canker, is based on the use of resistant or tolerant host genotypes. Field tolerance or resistance is not found in the most important commercial sweet orange cultivars available in the citrus-producing areas worldwide (38). It is known that the most resistant Rutaceae genotypes are some mandarins $(C$. reticulata - Ponkan, Tankan, and Sun Chu Sha, or C. unshiu Satsuma), Calamondin (C. mitus), and Kumquats (Fortunella spp.), but the resistance mechanism against $X$. citri subsp. citri remains to be determined. The development of more resistant citrus genotypes against $X$. citri subsp. citri is based mainly on genetic transformation (49). Previous studies indicate that exogenous genes from insects or Arabidopsis introduced into citrus plants have increased to some extent the resistance to citrus canker $(13,49)$. Furthermore, pathogen-derived resistance has been developed and applied in different crops to obtain resistant genotypes to plant pathogens (7,31). Recently, Yang et al. (49) demonstrated that the introduction of a disrupted pthA at the nuclear localization signals (NLS) motif was able to trigger host resistance against citrus canker. 
Many phytopathogenic bacteria harbor a range of effector proteins delivered into plant cells via a syringe-like apparatus known as the type III secretion system (TTSS) $(4,27)$. The interactions of these effectors with the plant cell can suppress and/or induce host defenses depending on the host-bacterium interaction. The $X$. citri subsp. citri genome is known to harbor a repertoire of bacterial effectors from different families: AvrBs3/PthA, HopX (AvrPphE), PopC, and AvrBs2 (19). For instance, the AvrBs3/PthA family belongs to the transcription activator-like effector family (TALE) and induces plant cell enlargement and hypertrophy (4). The HopX family members are modular proteins involved in avirulence activity and induction of cell death response (36). PopC family members are leucine-rich-repeat (LRR) proteins. LRR motifs are commonly involved in protein-protein mediation and are present in the major classes of resistance genes (27). The function of PopC proteins is not well understood.

Genetic variation in bacteria can be selected by different evolutionary forces. Host-pathogen interaction is one of them and can be expressed in the bacterium as different pathogenicity abilities, i.e., host range, aggressiveness, and/or fitness. Knowing the genetic diversity of a pathogen and its population structure may help to establish hypotheses regarding its evolutionary history, understand the interaction of the pathogen with the host, and define diagnostic methods and control strategies $(1,37,40,47)$. Information about the genetic structure of $X$. citri subsp. citri populations pathogenic to citrus in a small spatial scale is limited, and could provide insights into the genetic diversity, evolution, spatial movement of strains, and interactions between Xanthomonas and citrus hosts. Novel approaches against $X$. citri subsp. citri related with the host resistance engineering can be developed based on this information.

The objectives of the present study were: (i) the development of DNA primers and probes based on type III effector genes avrXacE1, avrXacE2, and avrXacE3, all members of the HopX family, avrBs2, pthA4, hpaF, and XAC3090 (leucine rich protein) coding for a PopC-like-LRR protein; and (ii) their application in evaluation of the genetic diversity of a Brazilian collection of $X$. citri subsp. citri strains. For comparison, the diversity was also evaluated with BOX elements - and enterobacterial repetitive intergenic consensus-polymerase chain reaction (ERIC-PCR), a common and useful technique used in studies of genetic diversity of pathogens.

\section{Materials and Methods}

Bacterial strains, and DNA extraction. In total, 157 strains of $X$. citri subsp. citri from 62 municipalities and 7 Brazilian states were used in this study (Mato Grosso [ $n=5]$, Mato Grosso do Sul $[n=4]$, Paraná $[n=44]$, Roraima $[n=3]$, Rio Grande do Sul $[n=$
13], Santa Catarina [ $n=8]$, and São Paulo $[n=80]$ ) (Table 1 and Fig. 1). The strain collection included the $X$. citri subsp. citri strain 306 (Xcc 306), sequenced by the Genoma Project/FAPESP (19). Thirty-seven and 27 strains, originating from two citrus groves located in São Paulo and Paraná (named Presidente Prudente and Ourizona, respectively), were also included. Most of the strains used in the present study were isolated from sweet orange plants (Citrus sinensis). DNA was extracted using the CTAB method (6). To test the reproducibility of the performed techniques, two independent DNA extractions were used for each strain.

Primer design, PCR, and PCR-restriction fragment length polymorphism (RFLP) analysis. Primers were designed with the Primer3 software using the complete sequence of Xcc 306 (GenBank accession number NC_003919.1). Specific primers were synthesized for the avrXacE1, avrXacE2, avrXacE3, avrBs2, pthA4, hpaF, and XAC3090 genes (Table 2). Primers were designed to hybridize in the flanking regions of the targeted genes to amplify complete copies of the target sequences. All these genes have a chromosomal location in Xcc 306, except avrXacE3 and pthA4, which are plasmid-borne.

Amplification reactions with primers AvrXacE1-F/R, AvrXacE2F/R, AvrXacE3-F/R, and Xac3090-F/R were performed in a total volume of $50 \mu \mathrm{l}$ in an Eppendorf Mastercycler. Each reaction contained $2 \mathrm{U}$ of Taq DNA polymerase (Invitrogen), $1 \times$ Taq buffer, 0.2 $\mathrm{mM}$ of mixed dNTPs, $2 \mathrm{mM} \mathrm{MgCl}_{2}$ (1.5 $\mathrm{mM} \mathrm{MgCl}_{2}$ for AvrXacE3), and $0.5 \mu \mathrm{M}$ of each primer (Invitrogen). The protocol used for the amplifications was the same for all primer pairs and consisted of an initial denaturing cycle at $94^{\circ} \mathrm{C} / 3$ min followed by 35 cycles at $94^{\circ} \mathrm{C} / 1 \mathrm{~min}, 65^{\circ} \mathrm{C} / 1 \mathrm{~min}$, and $72^{\circ} \mathrm{C} / 3 \mathrm{~min}$; and a final extension cycle at $72^{\circ} \mathrm{C} / 10 \mathrm{~min}$.

PCR analysis using primers AvrBs2-F/R, HpaF-F/R, and PthA4$\mathrm{F} / \mathrm{R}$ were performed in $50 \mu \mathrm{l}$ (total volume) mixtures containing 1 $\mathrm{U}$ of Phusion DNA polymerase (Finnzymes), $1 \times$ Phusion buffer, 5\% DMSO (except for AvrBs2), $0.2 \mathrm{mM}$ of mixed dNTPs, and 0.5 $\mu \mathrm{M}$ of each primer. The amplification conditions with primers AvrBs2-F/R consisted of $98^{\circ} \mathrm{C} / 35 \mathrm{~s}, 62^{\circ} \mathrm{C} / 35 \mathrm{~s}$, and $72^{\circ} \mathrm{C} / 45 \mathrm{~s}$ for 30 cycles plus an initial step of $98^{\circ} \mathrm{C} / 30 \mathrm{~s}$ and a final step of $72^{\circ} \mathrm{C} / 10 \mathrm{~min}$; and with primers $\mathrm{HpaF}-\mathrm{F} / \mathrm{R}$ and $\mathrm{PthA} 4-\mathrm{F} / \mathrm{R}$ consisted of $98^{\circ} \mathrm{C} / 10 \mathrm{~s}, 66^{\circ} \mathrm{C} / 10 \mathrm{~s}$, and $72^{\circ} \mathrm{C} / 50 \mathrm{~s}$ for 30 cycles plus an initial step of $98^{\circ} \mathrm{C} / 30 \mathrm{~s}$ and a final step of $72^{\circ} \mathrm{C} / 10 \mathrm{~min}$. The following endonucleases were used for PCR-RFLP analysis: EcoRI, EcoRII, EcoRV, HaeIII, HincII, PstI, PvuII, and SphI (Invitrogen); $A l u \mathrm{I}, B b v \mathrm{I}, P v u \mathrm{I}$, and NspI (New England BioLabs); BglI (Promega); and CfrI, ClaI, and TaqI (Fermentas), according to the manufacturer's instructions.

Southern blot. Primer sets and PCR conditions used for amplifying complete sequences of the seven selected genes of Xcc

Table 1. Brazilian states, year of isolation, and strains of Xanthomonas citri subsp. citri used in this study

\begin{tabular}{lll}
\hline Brazilian state & Year $^{\mathbf{a}}$ & Strain $^{\mathbf{b}}$ \\
\hline Mato Grosso & 1999,2002, and 2003 & IBSBF 1467, 1775, 1843, 1860, and 1861 \\
Mato Grosso do Sul & 1980,1994, and 2002 & IBSBF 223, 1050, 1767, and 1768 \\
Paraná & $1979,1986,1996,1997$, and 2005 & 306 (genome sequenced); FDC 121, 1182, 1183, 1184, 1186, 1187, 1188, 1189, 1190, \\
& & $1192,1194,1195,1257,1258,1259,1260,1261,1262,1265,1266,1267,1268,1269$, \\
& $1270,1272,1273,1274,1275 ;$ IAPAR 12845, 12851, 12853, 12856, 12858, 12859, \\
Rio Grande do Sul & 1993,1999, and 2001 & $12861,12863,12864,12870,12873,12875,12967,8905 ;$ and IBSBF 987 \\
& & FDC 605, 608, 625, 629; IAPAR 12973, 12976, 14002, 14004, 14006; IBSBF 1669, \\
Roraima & 1989,1990, and 1991 \\
Santa Catarina & IBSBF 1778, 1780, and 1803 \\
São Paulo & 1985 and 2001 & FDC 616, 617, 626, 628; IAPAR 714; IBSBF 1636, 1637, and 1992 \\
& $1980,1981,1988,1997,1998,1999$, & FDC 200, 201, 202, 210, 213, 214, 217, 274, 276, 277, 278, 279, 281, 282, 284, 285, \\
& 2000,2001, and 2005 & $287,288,291,292,293,294,295,296,297,299,300,302,304,306,307,308,309$, \\
& $310,312,359,363,1227,1279,1280,1281,1282,1283,1284,1285,1287,1288$, \\
& $1289 ;$ IAPAR 1233, 12353, 12405, 12418, 12701, 12708, 12710, 12714, 12826, \\
& & $12833,12969,12984,12988,12992,13000,13013,13016 ;$ IBSBF 222, 245, 283, 338, \\
& & $339,349,1350,1404,1421,1422,1474,1509,1515,1568$, and 1580 \\
\hline
\end{tabular}

\footnotetext{
${ }^{a}$ There are indicated only the different years when strains were isolated from field affected plants.

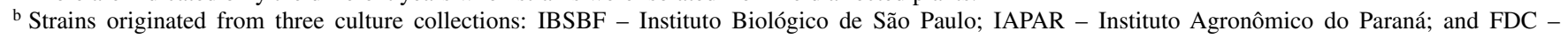
Fundecitrus.
} 
306 to be used as probes in Southern blot analysis were used as aforementioned. The bands corresponding to the expected fragments were purified and inserted into the plasmid vector pGEM-T Easy Vector System (Promega) according to the manufacturer's instructions. Samples of total DNA $(10 \mu \mathrm{g})$ of Xanthomonas strains were cleaved with AccI (Invitrogen), AflIII (New England BioLabs), AvaI (New England BioLabs), or BstXI (New England BioLabs) endonucleases, as presented in Table 2, according to the manufacturers' instructions and separated by electrophoresis in $1 \%$ agarose gels ( $50 \mathrm{~V}$ for $22 \mathrm{~h}$ ). The restriction patterns for each enzyme were predicted using the complete sequence of Xcc 306 allowing complete fragments containing each Type III effector gene. DNA fragments were transferred to nylon membranes (Hybond $\mathrm{N}+$, GE Healthcare). Probes were labeled and hybridization was performed for about $16 \mathrm{~h}$ at $42^{\circ} \mathrm{C}$, and detection was accomplished using the ECL kit (Direct Nucleic Acid Labeling) according to the manufacturer's recommendations (GE Healthcare).

BOX and ERIC-PCR. BOX and ERIC PCR analysis (18) were carried out with primers BOX1R, ERIC1R, and ERIC2 (35). Each PCR analysis was performed in $25-\mu$ l (total volume) mixtures containing $1 \times$ Taq buffer, $0.2 \mathrm{mM}$ of mixed dNTPs, $2.5 \mathrm{mM} \mathrm{MgCl}_{2}, 1$ $\mu \mathrm{M}$ of each primer, and $2 \mathrm{U}$ of Taq DNA polymerase (Invitrogen). Amplifications were carried out in a Eppendorf Mastercycler thermal cycler programmed for a denaturation initial step of $94^{\circ} \mathrm{C} / 5$ min, followed by 40 cycles at $94^{\circ} \mathrm{C} / 30 \mathrm{~s}, 48^{\circ} \mathrm{C} / 30 \mathrm{~s}$, and $72^{\circ} \mathrm{C} / 1$ min; and a final extension cycle at $72^{\circ} \mathrm{C} / 10 \mathrm{~min}$. The products were visualized under UV light in $2 \%$ agarose gels stained with ethidium bromide.

Data analysis. The genetic profiles identified by Southern blot were recorded as the absence (0) or presence (1) of bands. Only reproducible bands were considered positive. Each unique profile of bands was considered as a haplotype. A similarity matrix was calculated using the Dice coefficient, and a dendrogram was built by the UNJ (unweighted neighbor joining) method (22) using the software DarWIN 5.0 (CIRAD, Montpellier, France). The robustness of the tree was assessed by bootstrap analysis using the same program with 2,000 resamplings.

The correlations between distance matrices were tested globally by computing the Kendall's coefficient of concordance (W) among the distance matrices through a permutation test $(9,999$ permutations) with the 'CADM.global' function of the 'ape' package in $\mathrm{R}$ software (17). Kendall's W is a nonparametric statistic (no assumptions are made on the probability distribution of the values) that evaluates congruence among multiple rating systems, with $\mathrm{W}$ ranging from 0 (no agreement) to 1 (complete agreement) (32). The concordant and discordant distance matrices in the group were identified by Mantel tests that were carried out by using the 'CADM.post' function in 'ape' (17). The Holm's correction method for multiple testing was applied to the list of $P$ values produced in the a posteriori Mantel tests.

Allelic richness among strain collections was computed by a rarefaction method producing unbiased estimates due to uneven sample sizes (29). Analyses were performed with HP-RARE version 1.0 (30) using RFLP data for the two Brazilian states (São Paulo and Paraná) for which large strain numbers were available $\left(n_{\min }=44\right)$. Data derived from the AvrXacE1, AvrXacE2, AvrXacE3, and PthA4 probes (Southern analyses) were used.

The Brazilian strain collection was divided into 7 subcollections considering the region of origin and also the different strategies applied for control of citrus canker in Brazil. Only states with more than 7 strains were considered for the analysis. Seven subcollections were used for genetic analysis and were named after the mu-

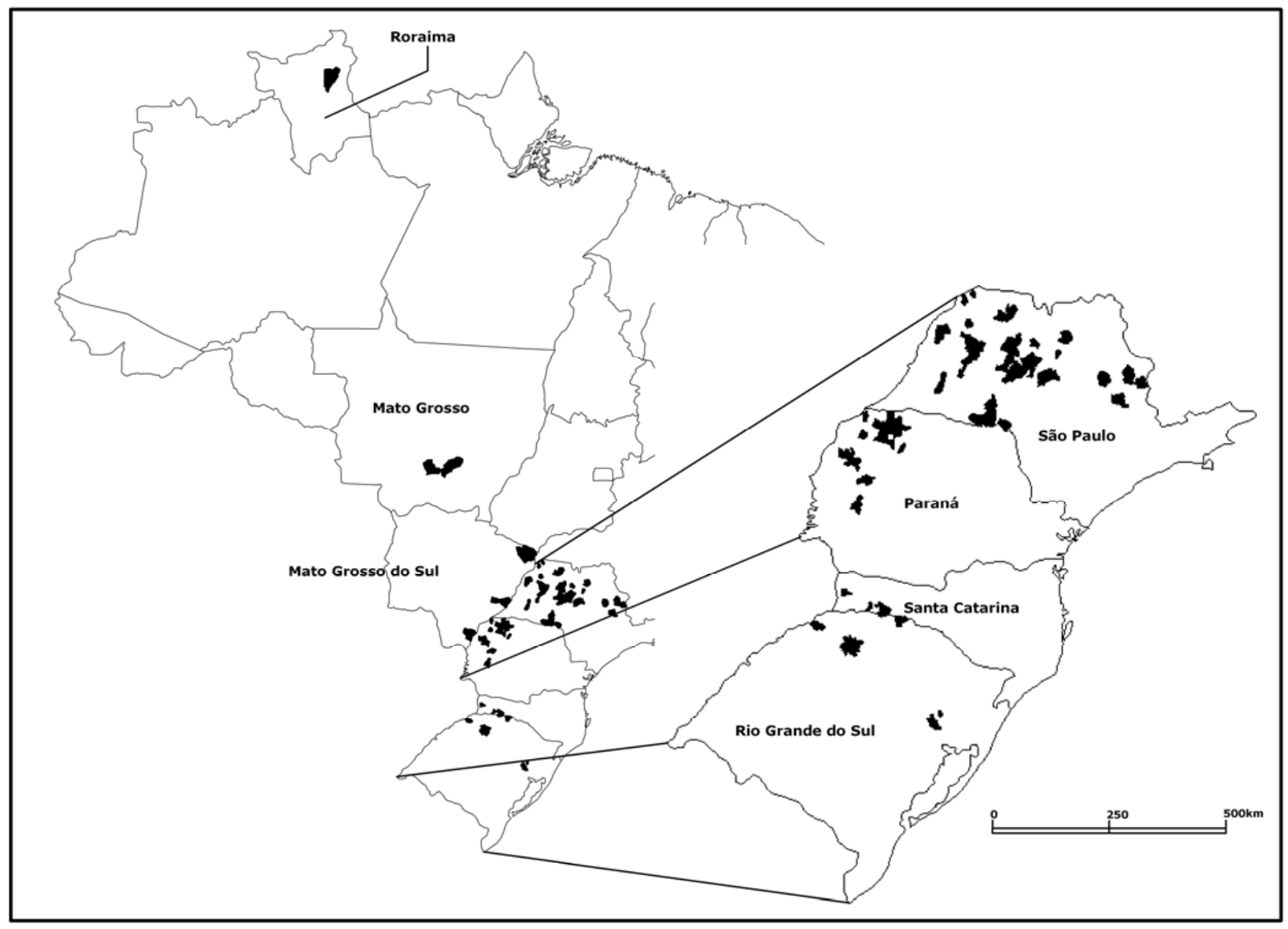

Fig. 1. Origin of Xanthomonas citri subsp. citri strains collected from Brazilian states. Municipalities where the strains originated are in black. 
nicipality, state, or region of origin. Santa Catarina and Rio Grande do Sul subcollections were composed of 8 and 13 strains, respectively. The São Paulo subcollection was composed of 42 strains from 30 municipalities. Also from São Paulo State, but not included in the São Paulo subcollection, the 38 strains from Presidente Prudente municipality formed an orchard population named after the municipality, as all the strains from this municipality (except one) were isolated in 2001 from 37 different citrus trees from the same citrus orchard. The same reasoning was used for the strains from Ourizona, Paraná State, forming an orchard population of 27 strains from the same citrus orchard. The Paraná subcollection was composed of 17 strains, not including the strains from Ourizona. The subcollections Paraná, Santa Catarina, and Rio Grande do Sul were further merged into another subcollection named Sul, representing the southern Brazilian states. The genetic differentiation ( $\mathrm{F}_{\mathrm{ST}}$ values) between the subcollections was estimated considering the frequency of haplotypes and calculated by an analysis of molecular variance (AMOVA) using the software Arlequin version 3.11 (20).

\section{Results}

DNA fragments of the expected size containing the avrXacE1, avrXacE2, avrBs2, hpaF, and XAC3090 genes occurred in all the strains tested in this study. Only one strain (IAPAR 12853) did not present the avrXacE3 fragment by PCR amplification or Southern blot analysis. No amplification or unspecific bands occurred for pthA4 after PCR in 13 strains (IAPAR 14004 and 14006; IBSBF 1636, 1669, 1989, 1991, and 1992; and FDC 605, 616, 617, 625, 626, and 1182), and bands of different sizes from strain Xcc 306 occurred in 8 strains (IAPAR 12826, 12833, and 12967; IBSBF 1350, 1778, 1780, and 1803; and FDC 1227). The PCR-RFLP results for the amplified fragments corresponding to avrXacEl (digested with the endonucleases BglI, HincII, PstI, CfrI, and NspI), avrXacE2 (BglI, HincII, PstI, EcoRI, and EcoRV), avrXacE3 (BbvI, BglI, HaeIII, HincII, and EcoRV), avrBs2 (BglI, ClaI, EcoRV, HincII, and PstI), hpaF (HincII, NspI, PstI, PvuII, and SphI), and XAC3090 (HincII, PstI, HaeIII, BbvI, and PvuI) genes did not reveal polymorphism in their nucleotide sequences. All amplified and cleaved fragments for these 6 genes with the respective endonucleases presented restriction profiles identical to those expected by in-silico analysis for Xcc 306. The restriction pattern identified for Xcc 306 by PCR-RFLP for pthA4 was as expected by in-silico analysis and did not differ from almost all other tested strains, except for 9 strains that presented different restriction patterns with $A l u \mathrm{I}, N s p \mathrm{I}, T a q \mathrm{I}$, and $P v u \mathrm{I}$ endonucleases (IAPAR 12826, 12833, 12967; IBSBF 1350, 1778, 1780, 1803; FDC 1227 and 1273), and also 13 strains with $B g l$ II (IAPAR 12826, 12833, 12967; IBSBF 1350, 1778, 1780, 1803; FDC 306, 308, $310,312,1227$, and 1273).

All 157 strains presented the same genetic pattern for both BOX and ERIC-PCR. Five fragments were amplified for each strain by BOX-PCR and 10 fragments by ERIC-PCR. A total of 49 haplotypes were identified by Southern blot analysis combining the results of all 7 probes. The probes corresponding to the genes $a v r B s 2$, XAC3090, and hpaF did not reveal polymorphisms in the collections (Table 3). Probes AvrXacE1, AvrXacE2, and AvrXacE3 allowed the identification of 7, 3, and 8 haplotypes, respectively. The PthA 4 probe showed the greatest diversity with 43 band positions, allowing the identification of 30 haplotypes. Band positions related to the pthA homologs that have been defined in the sequenced strain 306 were recorded in most but not all strains of $X$. citri subsp. citri from Brazil, suggesting sequence variation in

Table 2. Primers used to amplify and clone the avrXacE1, avrXacE2, avrXacE3, avrBs2, XAC3090 (leucine rich protein), hpaF, and pthA4 genes, and restriction enzymes used in Southern blot analysis

\begin{tabular}{|c|c|c|c|c|}
\hline Type III effector gene & Locus tag $^{\mathrm{a}}$ & Primer & Sequence $\left(5^{\prime} \rightarrow 3^{\prime}\right)$ & $\begin{array}{l}\text { Restriction enzymes } \\
\text { used in Southern blot }\end{array}$ \\
\hline \multirow{2}{*}{ avrXacE1 } & XAC0286 & AvrXacE1-F & TGAACGATAGGCAGCTGTTC & $A c c \mathrm{I}, B s t \mathrm{XI}$ \\
\hline & & AvrXacE1-R & GGAGAGCGACATGGGACTAT & \\
\hline \multirow{2}{*}{ avrXacE2 } & XAC3224 & AvrXacE2-F & CCGCTACCTAAGCAGAAGGA & $A v a \mathrm{I}, B s t \mathrm{XI}$ \\
\hline & & AvrXacE2-R & CAGGACGGTTACGCCAGTA & \\
\hline \multirow[t]{2}{*}{ avrXacE3 } & XACb0011 & AvrXacE3-F & AAATGATCAGCCGCTTGG & $A c c \mathrm{I}, B s t \mathrm{XI}$ \\
\hline & & AvrXacE3-R & TCCATCGTCACCAACTCAAG & \\
\hline \multirow[t]{2}{*}{ avrBs 2} & XAC0076 & AvrBs2-F & CCGCTACCTAAGCAGAAGGA & $A c c \mathrm{I}, B s t \mathrm{XI}$ \\
\hline & & AvrBs2-R & CAGGACGGTTACGCCAGTA & \\
\hline \multirow[t]{2}{*}{ leucine rich } & XАC3090 & Xac3090-F & CAGCTCAGCGACATAGAACG & $A c c \mathrm{I}, B s t \mathrm{XI}$ \\
\hline & & Xac3090-R & TCGTGTTTGCCCTTTACTGA & \\
\hline \multirow[t]{2}{*}{$h p a F$} & XАC0393 & HpaF-F & CATGCCTGCCGTTTAAAGT & $A c c \mathrm{I}, A f l \mathrm{III}$ \\
\hline & & HpaF-R & ACATCGACGATTGGCTTG & \\
\hline \multirow[t]{2}{*}{ pthA4 } & $\mathrm{XACb} 0065$ & PthA4-F & GCGGGAGTTTATGGATGGT & AflIII, AvaI \\
\hline & & PthA4-R & AGATTGCCAAGGATCTACGC & \\
\hline
\end{tabular}

Table 3. Xanthomonas citri subsp. citri haplotypes identified by Southern blot analysis with AvrXacE1, AvrXacE2, AvrXacE3, AvrBs2, Xac3090 (leucine rich protein), HpaF, and PthA4 DNA probes

\begin{tabular}{|c|c|c|}
\hline DNA probe & Haplotypes ${ }^{a}$ & $\begin{array}{l}\text { Total number } \\
\text { of haplotypes }\end{array}$ \\
\hline AvrXacE1 & $1(2), 2(8), 3(1), 4(1), 6(5), 7(52)$, and $8(88)$ & 7 \\
\hline AvrXacE2 & $1(1), 2(90)$, and $3(66)$ & 3 \\
\hline AvrXacE3 & $1(10), 3(3), 4(2), 5(60), 6(79), 7(1), 8(1)$, and $10(1)$ & 8 \\
\hline AvrBs2 & $1(157)$ & 1 \\
\hline Xac3090 & $1(157)$ & 1 \\
\hline $\mathrm{HpaF}$ & $1(157)$ & 1 \\
\hline PthA4 & $\begin{array}{l}\text { p1 (90), p2 (1), p3 (1), p4 (2), p5 (1), p6 (1), p7 (12), p8 (2), p9 (1), p10 (1), p11 (3), p12(1), p13 (1), p14 (1), } \\
\text { p15 (1), p16 (1), p17 (1), p18 (11), p19 (1), p20 (1), p21 (1), p22 (2), p23 (11), p24 (1), p25(1), p26 (2), p27 (1), } \\
\text { p28 (2), p29(1), and p30 (1) }\end{array}$ & 30 \\
\hline
\end{tabular}

a Number in parentheses corresponds to the total number of strains belonging to the related haplotype. 
flanking regions and/or the absence in these strains of some homologs described in strain 306. Most haplotypes identified with AvrXacE/PthA probes were represented by only one or a few strains for each DNA probe. Also, for most of these tested probes, one or two haplotypes occurred with highest frequencies in the collection, as haplotypes 7 and 8 (AvrXacE1), 2 and 3 (AvrXacE2), 5 and 6 (AvrXacE3), and p1 (PthA4) (Table 3). The number of copies of each studied gene identified by Southern blot varied within the strains, except for avrBs2, XAC3090, and hpaF, identified as one copy each. One to three copies occurred for avrXacE1, one to two for $a v r X a c E 2$, zero to three for $a v r X a c E 3$, and two to five for $p t h A$ (Fig. 2).

The Kendall's W statistics ( $\mathrm{W}=0.5171 ; p=0.0001)$ indicated a global congruence among the RFLP data derived from the four probes for which polymorphism was shown. A posteriori comparisons based on Mantel tests indicated a lack of positive correlation between data derived from the AvrXacE2 probe and other probes. This could be explained by the low number of haplotypes revealed with the AvrXacE2 probe. All other pairwise comparisons between probes based on Mantel tests yielded significant correlation between distances among haplotypes $(p \leq 0.0004)$. When all data were considered, overall allelic richness was 4.29 and 4.86 for São Paulo and Paraná, respectively. Most of the overall allelic richness was related to data derived from the PthA4 probe (data not shown).

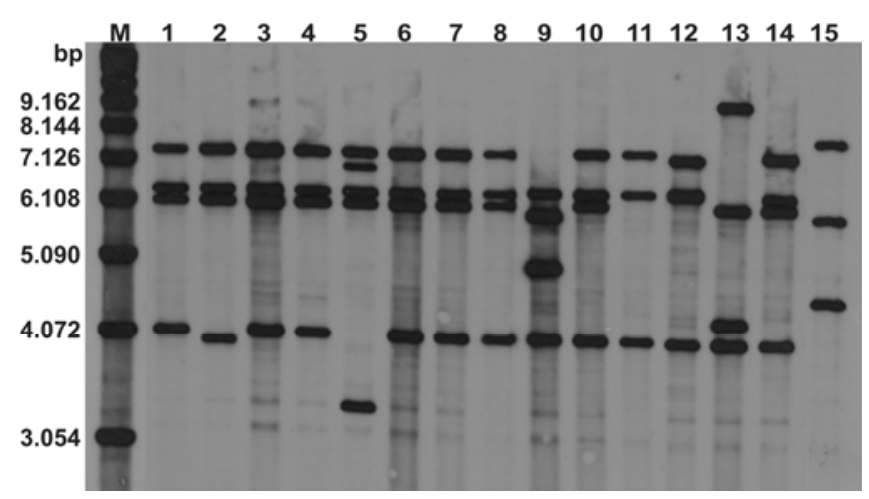

Fig. 2. Southern blot hybridization patterns with PthA4 DNA probe of Aval-digested genomic DNA from Brazilian strains of Xanthomonas citri subsp. citri. Columns 1 (strain 306), 3 (IBSBF 339), 4 (IBSBF 1050), 6 (IAPAR 714), 7 (IAPAR 13016), 8 (IAPAR 12969), 10 (IAPAR 12708), and 14 (IAPAR 12701): haplotype p1; columns 2 (IBSBF 222), 5 (IAPAR 12992), 9 (IAPAR 12710), 13 (IAPAR 12833), and 15 (IBSBF 1992): haplotypes p3, p19, p7, p18, and p16, respectively; and columns 11 (IAPAR 13000) and 12 (IAPAR 12714): haplotype p12. M: 1 kb DNA ladder (Invitrogen).
Six to 17 haplotypes were identified in the defined subcollections or orchard populations (Table 4). The greatest locus polymorphism was observed for strains from the subcollections, and the lowest polymorphism was observed in the orchard populations of Ourizona and Presidente Prudente. The Nei genetic diversity indexes were relatively high and varied from 0.65 (Ourizona) to 0.96 (Paraná). The mean number of differences between all pairs of haplotypes (pairwise differences) varied from 1.52 (Ourizona) to 12.62 (Rio Grande do Sul). Considering all 7 probes used, São Paulo presented 17 haplotypes, the highest number between all strain's collections (Tables 4 and 5). All subcollections presented one or few haplotypes as the most frequent, noted the haplotypes 13, 32, and 38 (Table 5). Strains from Mato Grosso, Mato Grosso do Sul, and Roraima corresponded to haplotypes 35 and 38, respectively. The PthA4 probe resulted in the higher number of haplotypes identified in the strain's collections, especially in São Paulo and Paraná (Table 6). For each subcollection, 2 to 5 haplotypes were identified with the Avr probes and 2 to 12 for PthA4. Only for Ourizona, the AvrXacE3 revealed more polymorphism than PthA4, considering the number of haplotypes identified. Higher variation in the frequency of haplotypes occurred within the subcollections $(93.72 \%)$ than among subcollections $(6.28 \%)$. Pairwise comparison analysis did not reveal any differences among the southern Brazilian subcollections, except for Santa Catarina and Rio Grande do Sul compared to Paraná (Table 7). The subcollections formed by strains isolated from the same groves (Presidente Prudente and Ourizona) and São Paulo differed from each other and from all other subcollections.

Although a relatively high number of haplotypes were identified in the Brazilian collection, only some haplotypes were genetically distant from all others, especially those originating from Rio Grande do Sul and Santa Catarina, as showed in Figure 3 with results of all 7 probes. Bootstrap values higher than 70 occurred only for branches formed by 9 haplotypes (numbers 1, 2, 3, 4, 5, 7, 8,9 , and 22), each of them represented by one to three strains only and originated from São Paulo (number 7), Rio Grande do Sul (numbers 1, 2, 4, 5, 8, and 22) and Santa Catarina (numbers 2, 3, 5, 8, and 9). A similar branching pattern for these aforementioned Brazilian states was observed for PthA4 (Fig. 4).

\section{Discussion}

São Paulo and southern states represent the most important citrus producing areas where citrus canker develops in Brazil. First detected in São Paulo in 1957, X. citri subsp. citri has induced citrus canker in the mentioned regions for decades, and two main control strategies are applied for this disease (8-12). The eradication of symptomatic and neighboring citrus plants is applied in

Table 4. Number of strains, haplotypes, polymorphic loci, Nei genetic index, and pairwise differences of Brazilian subcollections and orchard populations of Xanthomonas citri subsp. citri strains identified by Southern blot analysis with AvrXacE1, AvrXacE2, AvrXacE3, AvrBs2, Xac3090 (leucine rich protein), HpaF, and PthA4 DNA probes

\begin{tabular}{|c|c|c|c|c|c|}
\hline Brazilian collections $^{\mathbf{a}}$ & $\begin{array}{l}\text { Number of } \\
\text { strains }^{\mathbf{b}}\end{array}$ & $\begin{array}{l}\text { Number of } \\
\text { haplotypes }\end{array}$ & $\begin{array}{c}\text { Number of } \\
\text { polymorphic loci }(\%)^{d}\end{array}$ & $\begin{array}{l}\text { Genetic diversity } \\
\text { (Nei) }^{\mathrm{e}}\end{array}$ & $\begin{array}{l}\text { Mean number of } \\
\text { pairwise differences }\end{array}$ \\
\hline \multicolumn{6}{|l|}{ Subcollections } \\
\hline São Paulo & 42 & 17 & $38(54 \%)$ & 0.91 & 5.90 \\
\hline Paraná & 17 & 14 & $34(49 \%)$ & 0.96 & 7.25 \\
\hline Santa Catarina & 8 & 6 & $26(37 \%)$ & 0.93 & 9.29 \\
\hline Rio Grande do Sul & 13 & 9 & $28(40 \%)$ & 0.94 & 12.62 \\
\hline \multicolumn{6}{|l|}{ Orchard populations } \\
\hline Presidente Prudente & 38 & 13 & $16(23 \%)$ & 0.87 & 2.78 \\
\hline Ourizona & 27 & 6 & $6(9 \%)$ & 0.65 & 1.52 \\
\hline \multirow{2}{*}{\multicolumn{6}{|c|}{$\begin{array}{l}\text { Indicate the analyzed strain collections formed by strains from different Brazilian states (subcollections), and also the orchard populations formed by } \\
\text { strains originated from the same citrus groves in Presidente Prudente and Ourizona municipalities. }\end{array}$}} \\
\hline & & & & & \\
\hline \multicolumn{6}{|c|}{$\begin{array}{l}\text { c Total number of haplotypes identified by Southern blot analysis with DNA probes corresponding to the complete sequences of avrXacE1, avrXacE2, } \\
\text { avrXacE3, avrBs2, Xac3090 (leucine rich protein), hpaF, and pthA4 genes. }\end{array}$} \\
\hline \multirow{2}{*}{\multicolumn{6}{|c|}{$\begin{array}{l}\text { d Number of polymorphic fragments identified by Southern blot analysis in each strain collection or population, and percentage of polymorphic fragments } \\
\text { from the total number of fragments considered. } \\
\text { e Nei's genetic diversity index calculated using the software Arlequin version } 3.11(20) \text {. }\end{array}$}} \\
\hline & & & & & \\
\hline \multicolumn{6}{|c|}{ f Represents the number of different alleles between two Southern blot haplotypes, calculated using the software Arlequin version 3.11 (20). } \\
\hline
\end{tabular}


São Paulo only, where an official eradication program has been followed since the 1950s. Citrus canker was detected during the same time in Paraná State, and in the 1980s in Santa Catarina and Rio Grande do Sul. The eradication program was initially practiced in the southern citrus areas as well for a few years. It was later replaced by an integrated management approach to citrus canker, which is the current control strategy for nearly the last three decades in those states (8-10).

Theoretically, eradication procedures should markedly reduce the time of interaction between the pathogen and host, whereas integrated management of the disease allows a more extended pe- riod of interaction. Very interestingly, a relatively high genetic diversity was found in strains from all Brazilian provinces irrespective of the strategy used for citrus canker control. Due to the eradication program, surveys conducted between 1999 and 2010 revealed incidences of blocks with citrus canker lower than $0.45 \%$ and that $>99.9 \%$ of the sweet orange trees are not infected with $X$. citri subsp. citri $(11,12)$. No official surveys are conducted in the southern areas in Brazil, but citrus canker is endemic in most of Paraná, Santa Catarina, and Rio Grande do Sul states, where since the 1990s no plant and orchard eradications are officially applied. Despite these very low levels of disease in São Paulo State, allelic

Table 5. Number and percentage of haplotypes identified by Type III effector genes in subcollections and orchard populations of Xanthomonas citri subsp. citri by Southern blot analysis

\begin{tabular}{|c|c|c|c|c|c|c|c|}
\hline \multirow[b]{2}{*}{ Haplotype $^{c}$} & \multicolumn{4}{|c|}{ Subcollections $^{\mathrm{a}}$} & \multicolumn{2}{|c|}{ Orchard populations $^{b}$} & \multirow{2}{*}{$\begin{array}{c}\text { All Brazilian } \\
\text { strains }^{\mathrm{d}}\end{array}$} \\
\hline & São Paulo & Paraná & Santa Catarina & Rio Grande do Sul & Presidente Prudente & Ourizona & \\
\hline 1 & & & & $2(15.38)$ & & & $2(1.27)$ \\
\hline 2 & & & $1(12.50)$ & $2(15.38)$ & & & $3(1.91)$ \\
\hline 3 & & & $1(12.50)$ & & & & $1(0.64)$ \\
\hline 4 & & & & $1(7.69)$ & & & $1(0.64)$ \\
\hline 5 & & & $2(25.00)$ & $1(7.69)$ & & & $3(1.91)$ \\
\hline 6 & & $1(5.88)$ & & & & & $1(0.64)$ \\
\hline 7 & $1(2.38)^{\mathrm{e}}$ & & & & & & $1(0.64)$ \\
\hline 8 & & & $2(25.00)$ & $1(7.69)$ & & & $3(1.91)$ \\
\hline 9 & & & $1(12.50)$ & & & & $1(0.64)$ \\
\hline 10 & & & & $1(7.69)$ & & & $1(0.64)$ \\
\hline 11 & & & & & & $1(3.70)$ & $1(0.64)$ \\
\hline 12 & & $1(5.88)$ & & & & & $1(0.64)$ \\
\hline 13 & $5(11.90)$ & $4(23.53)$ & & $3(23.08)$ & $1(2.63)$ & $15(55.56)$ & $28(17.83)$ \\
\hline 14 & & $1(5.88)$ & & & & & $1(0.64)$ \\
\hline 15 & & & & & $1(2.63)$ & & $1(0.64)$ \\
\hline 16 & & & & & $1(2.63)$ & & $1(0.64)$ \\
\hline 17 & & $1(5.88)$ & & & $3(7.89)$ & & $4(2.55)$ \\
\hline 18 & $1(2.38)$ & $1(5.88)$ & & & & & $2(1.27)$ \\
\hline 19 & & $1(5.88)$ & & & & & $1(0.64)$ \\
\hline 20 & $1(2.38)$ & & & & & & $1(0.64)$ \\
\hline 21 & $1(2.38)$ & & & & & & $1(0.64)$ \\
\hline 22 & & & & $1(7.69)$ & & & $1(0.64)$ \\
\hline 23 & $1(2.38)$ & & & & & & $1(0.64)$ \\
\hline 24 & $5(11.90)$ & & & & & & $5(3.18)$ \\
\hline 25 & & $1(5.88)$ & & & & & $1(0.64)$ \\
\hline 26 & & $1(5.88)$ & & & & & $1(0.64)$ \\
\hline 27 & $1(2.38)$ & & & & & & $1(0.64)$ \\
\hline 28 & & $1(5.88)$ & & & & & $1(0.64)$ \\
\hline 29 & & & & & $3(7.89)$ & $3(11.11)$ & $6(3.82)$ \\
\hline 30 & & $1(5.88)$ & & & & & $1(0.64)$ \\
\hline 31 & & & & & $1(2.63)$ & & $1(0.64)$ \\
\hline 32 & $4(9.52)$ & & $1(12.50)$ & & $9(23.68)$ & $1(3.70)$ & $15(9.55)$ \\
\hline 33 & & & & & $1(2.63)$ & & $1(0.64)$ \\
\hline 34 & & & & & $2(5.26)$ & & $2(1.27)$ \\
\hline 35 & & & & & & & $1(0.64)$ \\
\hline 36 & $1(2.38)$ & & & & & & $1(0.64)$ \\
\hline 37 & & & & & & $1(3.70)$ & $1(0.64)$ \\
\hline 38 & $10(23.81)$ & & & $1(7.69)$ & $9(23.68)$ & $6(22.22)$ & $37(23.57)$ \\
\hline 39 & $1(2.38)$ & & & & & & $1(0.64)$ \\
\hline 40 & & $1(5.88)$ & & & $5(13.16)$ & & $6(3.82)$ \\
\hline 41 & & $1(5.88)$ & & & & & $1(0.64)$ \\
\hline 42 & $1(2.38)$ & & & & & & $1(0.64)$ \\
\hline 43 & & & & & $1(2.63)$ & & $1(0.64)$ \\
\hline 44 & $2(4.76)$ & & & & & & $2(1.27)$ \\
\hline 45 & $5(11.90)$ & & & & & & $5(3.18)$ \\
\hline 46 & $1(2.38)$ & & & & & & $1(0.64)$ \\
\hline 47 & $1(2.38)$ & & & & & & $1(0.64)$ \\
\hline 48 & & & & & $1(2.63)$ & & $1(0.64)$ \\
\hline 49 & & $1(5.88)$ & & & & & $1(0.64)$ \\
\hline Number of strains $\mathrm{s}^{\mathrm{f}}$ & 42 & 17 & 8 & 13 & 38 & 27 & 157 \\
\hline
\end{tabular}

${ }^{a}$ Brazilian strain collections originated from São Paulo, Paraná, Santa Catarina, and Rio Grande do Sul states.

${ }^{\mathrm{b}}$ Populations formed by strains from two citrus groves located in Presidente Prudente (São Paulo State) and Ourizona (Paraná State) municipalities.

${ }^{c}$ Haplotypes identified by Southern blot analysis with AvrXacE1, AvrXacE2, AvrXacE3, AvrBs2, Xac3090 (leucine rich protein), HpaF, and PthA4 DNA probes.

d Refers to all studied Brazilian strains (157 strains of X. citri subsp. citri), including São Paulo, Paraná, Santa Catarina, Rio Grande do Sul, Mato Grosso, Mato Grosso do Sul, and Roraima states.

${ }^{e}$ Number of strains identified as the related haplotype and, between parentheses, percentage of the haplotype in the subcollection or orchard population.

${ }^{\mathrm{f}}$ Total number of strains from each subcollection or orchard population. 
Table 6. Number and percentage of haplotypes identified by AvrXacE1, AvrXacE2, AvrXacE3, and PthA4 DNA probes in subcollections and orchard populations of Xanthomonas citri subsp. citri by Southern blot analysis

\begin{tabular}{|c|c|c|c|c|c|c|}
\hline \multirow{2}{*}{$\begin{array}{l}\text { DNA } \\
\text { probe/haplotype }^{c}\end{array}$} & \multicolumn{4}{|c|}{ Subcollections $^{\mathbf{a}}$} & \multicolumn{2}{|c|}{ Orchard populations $^{b}$} \\
\hline & São Paulo & Paraná & Santa Catarina & Rio Grande do Sul & Presidente Prudente & Ourizona \\
\hline \multicolumn{7}{|l|}{ AvrXacE1 } \\
\hline 1 & & & & $2(15.39)$ & & \\
\hline 2 & & & $4(50.00)$ & $4(30.77)$ & & \\
\hline 3 & & $1(5.88)$ & & & & \\
\hline 4 & $1(2.38)^{\mathrm{d}}$ & & & & & \\
\hline 6 & & & $3(37.50)$ & $2(15.39)$ & & \\
\hline 7 & $15(35.72)$ & $11(64.71)$ & & $4(30.77)$ & $6(15.79)$ & $16(59.26)$ \\
\hline 8 & $26(61.90)$ & $5(29.41)$ & $1(12.50)$ & $1(7.68)$ & $32(84.21)$ & $11(40.74)$ \\
\hline \multicolumn{7}{|l|}{ AvrXacE2 } \\
\hline 1 & & $1(5.88)$ & & & & \\
\hline 2 & $18(42.86)$ & $13(76.47)$ & $6(75.00)$ & $10(76.92)$ & $22(57.90)$ & $20(74.07)$ \\
\hline 3 & $24(57.14)$ & $3(17.65)$ & $2(25.00)$ & $3(23.08)$ & $16(42.10)$ & $7(25.93)$ \\
\hline \multicolumn{7}{|l|}{ AvrXacE3 } \\
\hline 1 & & & $4(50.00)$ & $6(46.16)$ & & \\
\hline 3 & & & $2(25.00)$ & $1(7.69)$ & & \\
\hline 4 & & $1(5.88)$ & & & & $1(3.70)$ \\
\hline 5 & $16(38.10)$ & $10(58.82)$ & & $5(38.46)$ & $10(26.32)$ & $19(70.37)$ \\
\hline 6 & $25(59.52)$ & $5(29.42)$ & $1(12.50)$ & $1(7.69)$ & $28(73.68)$ & $7(25.93)$ \\
\hline 7 & $1(2.38)$ & & & & & \\
\hline 8 & & & $1(12.50)$ & & & \\
\hline 10 & & $1(5.88)$ & & & & \\
\hline \multicolumn{7}{|l|}{ PthA4 } \\
\hline 1 & $21(50.00)$ & $5(29.41)$ & $1(12.50)$ & $4(30.77)$ & $22(57.90)$ & $26(96.30)$ \\
\hline 2 & $1(2.38)$ & & & & & \\
\hline 3 & & $1(5.88)$ & & & & \\
\hline 4 & & & & & $2(5.26)$ & \\
\hline 5 & & & & & & $1(3.70)$ \\
\hline 6 & & & & & $1(2.63)$ & \\
\hline 7 & & $2(11.77)$ & & & $10(26.32)$ & \\
\hline 8 & & $1(5.88)$ & & & & \\
\hline 9 & & $1(5.88)$ & & & & \\
\hline 10 & & $1(5.88)$ & & & & \\
\hline 11 & $2(4.76)$ & $1(5.88)$ & & & & \\
\hline 12 & & $1(5.88)$ & & & & \\
\hline 13 & & $1(5.88)$ & & & & \\
\hline 14 & $1(2.38)$ & & & & & \\
\hline 15 & & $1(5.88)$ & & & & \\
\hline 16 & & & & $1(7.69)$ & & \\
\hline 17 & & & & & $1(2.63)$ & \\
\hline 18 & & & $5(62.50)$ & $6(46.15)$ & & \\
\hline 19 & & & $1(12.50)$ & & & \\
\hline 20 & $1(2.38)$ & & & & & \\
\hline 21 & $1(2.38)$ & & & & & \\
\hline 22 & $2(4.76)$ & & & & & \\
\hline 23 & $10(23.81)$ & & & $1(7.69)$ & & \\
\hline 24 & $1(2.38)$ & & & & & \\
\hline 25 & $1(2.38)$ & & & & & \\
\hline 26 & $1(2.38)$ & $1(5.88)$ & & & & \\
\hline 27 & & & $1(12.50)$ & & & \\
\hline 28 & & & & & $2(5.26)$ & \\
\hline 29 & & $1(5.88)$ & & & & \\
\hline 30 & & & & $1(7.69)$ & & \\
\hline Number of strains ${ }^{\mathrm{e}}$ & 42 & 17 & 8 & 13 & 38 & 27 \\
\hline
\end{tabular}

a Brazilian strain collections originated from São Paulo, Paraná, Santa Catarina, and Rio Grande do Sul states.

${ }^{b}$ Populations formed by strains from two citrus groves located in Presidente Prudente (São Paulo state) and Ourizona (Paraná state) municipalities.

${ }^{\mathrm{c}}$ Haplotypes identified by Southern blot analysis with AvrXacE1, AvrXacE2, AvrXacE3, and PthA4 DNA probes.

d Number of strains identified as the indicated haplotype and, between parentheses, percentage of the haplotype in the subcollection or orchard population to each DNA probe.

${ }^{\mathrm{e}}$ Total number of strains from each subcollection or orchard population.

Table 7. $\mathrm{F}_{\mathrm{ST}}$ values calculated to compare haplotype frequencies in the strain subcollections and orchard populations of Xanthomonas citri subsp. citri identified by Southern blot analysis with AvrXacE1, AvrXacE2, AvrXacE3, AvrBs2, Xac3090 (leucine rich protein), HpaF, and PthA4 DNA probes

\begin{tabular}{lccccc}
\hline Brazilian strain collections & Paraná & São Paulo & Santa Catarina & Rio Grande do Sul & Presidente Prudente \\
\hline São Paulo & $0.0429^{* a}$ & - & - & - & - \\
Santa Catarina & $0.0566^{* *}$ & $0.0741^{*}$ & - & - & - \\
Rio Grande do Sul & -0.0004 & $0.0367^{*}$ & 0.0105 & - & - \\
Presidente Prudente & $0.0705^{* *}$ & $0.0314^{*}$ & $0.0756^{*}$ & $0.0756^{* *}$ & - \\
Ourizona & $0.0837^{*}$ & $0.1099^{* *}$ & $0.2360^{* *}$ & $0.0840^{*}$ & $0.1634^{* *}$ \\
\hline
\end{tabular}

${ }^{a} F_{\text {ST }}$ values were calculated by analysis of molecular variance (AMOVA) using the software Arlequin version $3.11(20)$. * indicates $P=0.05$, and ** indicates $P=0.01$ for each comparison. 
richness, computed from Southern blot analysis for strains originating from São Paulo (where eradication is still undertaken) and Paraná (where IPM is implemented), yielded similar values. The sampling periods were 1980 to 2005 and 1986 to 2005 for strains collected in São Paulo and Paraná states, respectively. Most of the recorded polymorphism was linked to the PthA4 probe, for which 30 haplotypes differed in terms of number of homologs and size of the hybridizing fragments. All X. citri subsp. citri strains studied so far were found to carry a $p t h A$ homolog, and 133 strains presented the $p t h A 4$, identified by fragment similarity (size) with the fully
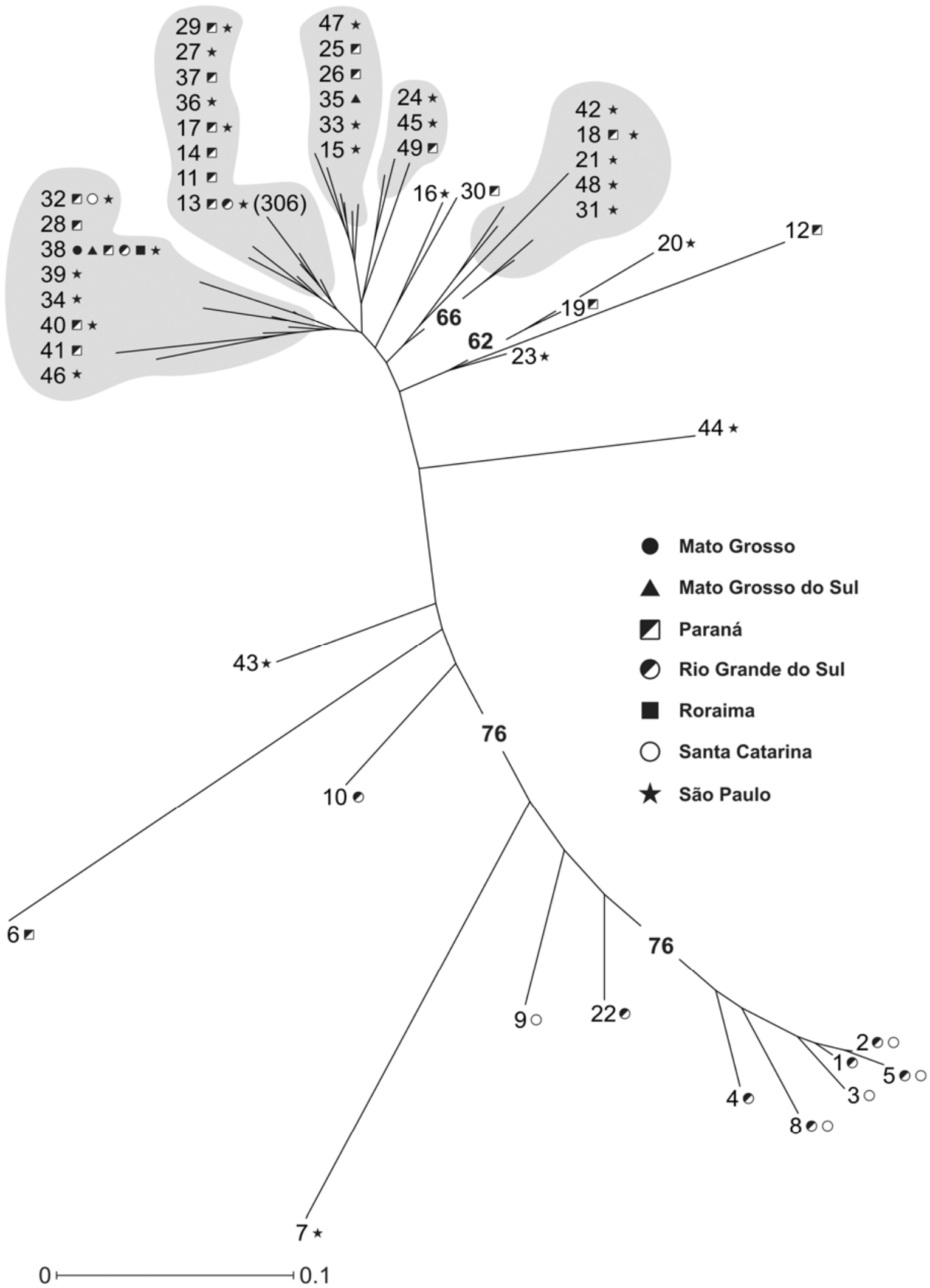

Fig. 3. Unweighted neighbor joining tree (Dice coefficient) showing the genetic diversity of 49 haplotypes identified by Type III effector genes in a Xanthomonas citri subsp. citri strain collection from Brazil. 
sequenced strain Xcc 306 by Southern analysis. The 17.5 nearly identical direct tandem repeats present in the pthA4 homolog are essential for elicitation of citrus canker disease (5). Direct tandem repeats are leucine-rich sequences of 102 bp each, known as an active site for unequal crossing-over and homologous recombination (39). The pthA genes were found plasmid-borne in the fully sequenced strain Xcc 306 (19). Thus, such diversity is likely due to variation in the number and relative position of the avr/pthA genes in the $X$. citri subsp. citri genome, rearrangements of plasmids containing those genes linked to horizontal transfer, and recombination at and outside of the direct tandem repeat sequences in the pthA genes. Interestingly, only one or two haplotypes occurred within highest frequencies in each subcollection for AvrXacE/ PthA4 probes and seem to be all genetically similar to one another and to most of the haplotypes (Figs. 3 and 4). However, the frequency of most genetically distant haplotypes was low, and they originated almost exclusively from Rio Grande do Sul and Santa Catarina, suggesting that strains with a different origin may have been introduced in these states.

Thirty-seven and 27 strains were isolated from only two citrus groves over a single year in Presidente Prudente, São Paulo in
2001, and Ourizona, Paraná in 2005, respectively. Their analysis using the panel of techniques reported herein yielded 19 different haplotypes, an unexpectedly high amount of diversity. Based on Southern/PCR-RFLP analysis with the pthA homolog, six and two haplotypes were identified in Presidente Prudente and Ourizona, respectively. The corresponding Nei's genetic diversity indexes for these subcollections were 0.87 and 0.65 , respectively, when pooled datasets were considered. However, these two orchard populations presented the smallest values of polymorphic loci and pairwise differences between haplotypes, as compared to statewide strain collections. These two areas have been naturally infected by $X$. citri subsp. citri for at least two decades, and therefore share a relatively long history of local epidemics. The trees in Ourizona are located in a commercial grove, whereas in Presidente Prudente the grove belonged to an experimental station and was used for studies of the citrus canker epidemiology under simulated endemic occurrence. This experimental station was launched in the early 1980s. By that time, the first citrus trees were planted, followed by a single inoculation of $X$. citri subsp. citri in 1982. All other citrus trees grown thereafter in the station were "naturally" infected with $X$. citri subsp. citri by the inoculum previously introduced in the

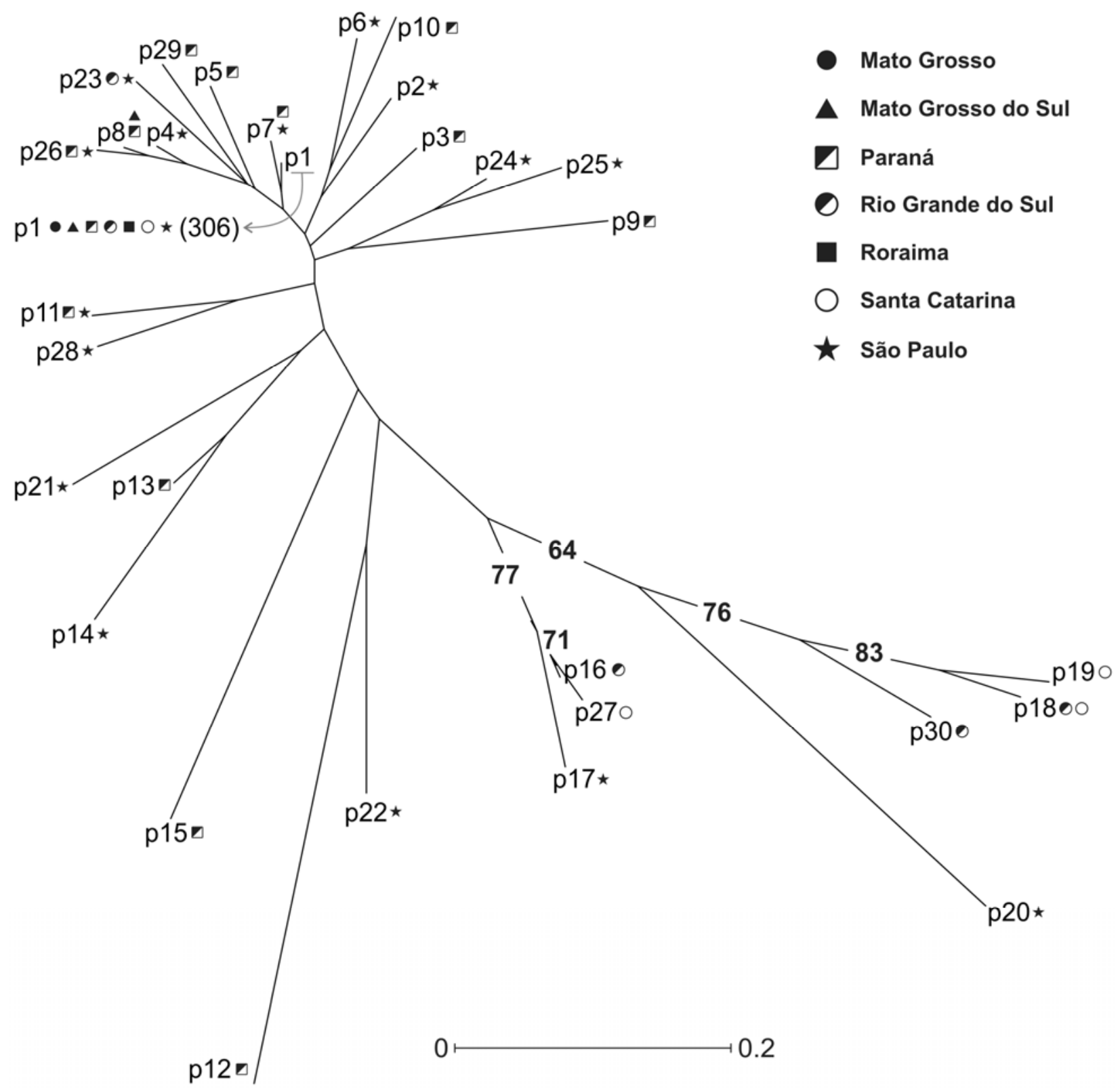

Fig. 4. Unweighted neighbor joining tree (Dice coefficient) showing the genetic diversity of 30 haplotypes (indicated by the "p") identified by PthA4 DNA probe used in Southern blot in a Xanthomonas citri subsp. citri strain collection from Brazil. 
area. Thus, we hypothesize that the high genetic diversity observed for X. citri subsp. citri strains from both orchards reflected the relatively long history of the disease in that area.

Although 49 haplotypes were identified in 157 X. citri subsp. citri strains, the results presented here revealed short genetic distances among almost all haplotypes, especially those highly frequent in the subcollections, and not robust bootstrap values in the UNJ dendrograms. Different techniques have been used to assess the genetic diversity of $X$. citri subsp. citri based on putative neutral markers $(14,16,18,34)$. Polymorphism was recently observed within world collections of $X$. citri subsp. citri using rep-PCR (18), insertion sequence-LM-PCR (14), AFLP, and multi locus variable number of tandem repeats analysis (MLVA) $(15,16)$. The analysis of the selected effector genes used in the present work was useful for the identification of variability among $X$. citri subsp. citri strains originating from close geographic regions, and reveals the dynamics of avr/pth genes in the pathogen population.

In Brazil, X. citri subsp. citri was first detected in the late 1950s in São Paulo and Paraná states, in the 1980s in most of the southern states, and only in 2003 in Roraima. Our results indicate that haplotypes 13, 32, and 38 are relatively widespread in Brazil. The occurrence of identical haplotypes in distant Brazilian regions may be explained by transport of infected vegetal material. Moreover, multiple independent introductions of $X$. citri subsp. citri may have occurred over time, as supposed in Florida, USA (26). We speculate that the $X$. citri subsp. citri population in Brazil originated from one or a few strains introduced in São Paulo in the 1950s or earlier. Immediately after the first official detection of citrus canker in São Paulo in 1957, X. citri subsp. citri was also detected in Paraná and Mato Grosso do Sul states. Probably São Paulo and Paraná populations of $X$. citri subsp. citri originated from the same genotypic strains. However, the populations in Rio Grande do Sul and Santa Catarina, states where $X$. citri subsp. citri was detected decades later, may have been formed or influenced by additional pathogen introductions. The geography and relative proximity of the southern states, especially Santa Catarina and Rio Grande do Sul, and neighbor countries with endemic occurrence of citrus canker in South America (Argentina, Paraguay, and Uruguay) could have facilitated the exchange of infected plant material, which in turn led to the establishment of relatively different $X$. citri subsp. citri populations. This hypothesis can explain the large differences observed between subcollections from Rio Grande do Sul/Santa Catarina and all other Brazilian subcollections. A broad and multi-method for genetic characterization of $X$. citri subsp. citri strains from South American countries, as previously done in Asia (15), would be necessary to better understand the genetic structure of this pathogen in Brazil.

Identification of the components of the gene-for-gene interaction and its association with well-defined phenotypes (susceptible or resistant) allowed the establishment of strategies for the deployment of selected genes into different varieties as sources of resistance (2). The $a v r$ genes used in the present study are likely not directly involved in causing canker symptoms like $p t h A$ from the AvrBs3/PthA family (44). As demonstrated by Al-Saadi et al. (5), pthA is essential for elicitation of citrus canker disease, but not for host-range variation. However, Yang et al. (49) demonstrated that the interruption of the nuclear localization signals (NLS) of pthA genes induced host resistance against citrus canker. Type III effectors are delivered into the host cell and interfere with defense responses. Except for pthA, the phenotype of the interaction involving the bacterial effectors used as DNA probes in the present work with the host is not known. As demonstrated, the bacterial effectors from the families AvrBs3/PthA, HopX (AvrPphE), PopC, and AvrBs2 are widespread in the $X$. citri subsp. citri collection, indicating their possible participation in the pathogen-host interaction. Essential genes for pathogenicity and host interaction are target candidates in the search for the corresponding resistance genes in host/no host plants and the generation of plants with effective and durable resistance (33).
We conclude that the counter-intuitive large $p t h A$-based diversity observed in São Paulo leads to at least two nonexclusive hypotheses, which would be dependent on the primary mode of $X$. citri subsp. citri spread in this state. A predominance of human-assisted spread would imply the occurrence of multiple migration events over the years. A predominance of natural spread through winddriven rains from undetected or incompletely eradicated foci would imply a relative immediacy of plasmid transfer among strains and/or genetic reorganization at transcription activator-like effector family (TALE) loci or at flanking sites on the plasmids that bear them. This issue should be studied further and a more thorough surveillance system combining extensive high throughput genotyping such as MLVA and typing of TALE genes in clonal complexes would be of interest for an improved understanding of the epidemiology of $X$. citri subsp. citri.

\section{Acknowledgments}

We thank Franklin Behlau for critically reviewing this manuscript. This work was financed by Fapesp (Process number 2007/01431-4) and CNPq (Process number 300231/2008-3)

\section{Literature Cited}

1. Adhikari, T. B., Mew, T. W., and Leach, J. E. 1999. Genotypic and pathotypic diversity in Xanthomonas oryzae pv. oryzae in Nepal. Phytopathology 89:687-694.

2. Adhikari, T. B., Vera Cruz, C. M., Zhang, Q., Nelson, R. J., Skinner, D. Z., Mew, T. W., and Leach, J. E. 1995. Genetic diversity of Xanthomonas oryzae pv. oryzae in Asia. Appl. Environ. Microbiol. 61:966-971.

3. Ah-You, N., Gagnevin, L., Grimont, P. A. D., Brisse, S., Nesme, X., Chiroleu, F., Bui Thi Ngoc, L., Jouen, E., Lefeuvre, P., Vernière, C., and Pruvost, O. 2009. Polyphasic characterization of xanthomonads pathogenic to members of the Anacardiaceae and their relatedness to species of Xanthomonas. Int. J. Syst. Evol. Microbiol. 59:306-318.

4. Alfano, J. R., and Collmer, A. 2004. Type III secretion system effector proteins: Double agents in bacterial disease and plant defense. Annu. Rev. Phytopathol. 42:385-414.

5. Al-Saadi, A., Reddy, J. D., Duan, Y. P., Brunings, A. M., Yuan, Q., and Gabriel, D. W. 2007. All five host-range variants of Xanthomonas citri carry one pthA homolog with 17.5 repeats that determines pathogenicity on citrus, but none determine host-range variation. Mol. Plant-Microbe Interact. 20:934-943.

6. Ausubel, F. M., Brent, R., Kingston, R. E., Moore, D. D., Seidman, J. G., Smith, J. A., and Struhl, K. 1995. Current Protocols in Molecular Biology. Wiley, New York.

7. Baulcombe, D. C. 1996. Mechanisms of pathogen-derived resistance to viruses in transgenic plants. Plant Cell 8:1833-1844.

8. Behlau, F., Belasque, J., Jr., Bergamin Filho, A., Graham, J. H., Leite R. P., Jr., and Gottwald, T. R. 2008. Copper sprays and windbreaks for control of citrus canker on Young Orange trees in southern Brazil. Crop Prot. 27:807813.

9. Behlau, F., Belasque, J., Jr., Bergamin Filho, A., and Leite, R. P., Jr. 2007. Incidência e severidade de cancro cítrico em laranja 'Pêra Rio' sob condições de controle químico e proteção com quebra-vento. Fitopatol. Bras. 32:311-317

10. Behlau, F., Belasque, J., Jr., Graham, J. H., and Leite R. P., Jr. 2010. Effect of frequency of copper applications on control of citrus canker and the yield of young bearing sweet orange trees. Crop Prot. 29:300-305.

11. Belasque, J., Jr., Barbosa, J. C., Bergamin Filho, A., and Massari, C. A. 2010. Prováveis consequências do abrandamento da metodologia de erradicação do cancro cítrico no Estado de São Paulo. Trop. Plant Pathol 35:314-317.

12. Belasque, J., Jr., Gimenes-Fernandes, N., and Massari, C. A. 2009. O sucesso da campanha de erradicação do cancro cítrico no Estado de São Paulo, Brasil. Sum. Phytopathol. 35:91-92.

13. Boscariol, R. L., Monteiro, M., Takahashi, E. K., Chabregas, S. M., Vieira, M. L., Vieira, L. G. E., Pereira, L. F. P., Mourão Filho, F. A. A., Cardoso, S C., Christiano, R. S. C., Bergamin Filho, A., Barbosa, J. M., Azevedo, F. A., and Mendes, B. M. J. 2006. Attacin A gene from Tricloplusia ni reduces susceptibility to Xanthomonas axonopodis pv. citri in transgenic Citrus sinensis 'Hamlin'. J. Am. Soc. Hortic. Sci. 13:530-536.

14. Bui Thi Ngoc, L., Vernière, C., Belasque, J., Jr., Vital, K., Sebastien, B., Gagnevin, L., and Pruvost, O. 2008. Ligation-mediated PCR, a fast and reliable technique for insertion sequence-based typing of Xanthomonas citri pv. citri. FEMS Microbiol. Let. 288:33-39.

15. Bui Thi Ngoc, L., Vernière, C., Jarne, P., Brisse, S., Guérin, F., Boutry, S Gagnevin, L., and Pruvost, O. 2009. From local surveys to global surveillance: Three high-throughput genotyping methods for epidemiological monitoring of Xanthomonas citri pv. citri pathotypes. Appl. Environ. Microbiol. 75:1173-1184

16. Bui Thi Ngoc, L., Vernière, C., Jouen, E., Ah-You, N., Lefeuvre, P., Chiro- 
leu, F., Gagnevin, L., and Pruvost, O. 2010. Amplified fragment length polymorphism and multilocus sequence analysis-based genotypic relatedness among pathogenic variants of Xanthomonas citri pv. citri and Xanthomonas campestris pv. bilvae. Int. J. Syst. Evol. Microbiol. 60:515-525.

17. Campbell, V., Legendre, P., and Lapointe, F. J. 2009. Assessing congruence among ultrametric distance matrices. J. Classif. 26:103-117.

18. Cubero, J., and Graham, J. H. 2002. Genetic relationship among worldwide strains of Xanthomonas causing canker in citrus species and design of new primers for their identification by PCR. Appl. Environ. Microbiol. 68:12571264.

19. Da Silva, A. C. R., Ferro, J. A., Reinach, F. C., Farah, C. S., Furlan, L. R., Quaggio, R. B., Monteiro-Vitorello, C. B., Van Sluys, M. A., Almeida, N. F., Alves, L. M. C., Amaral, A. M., Bertolini, M. C., Camargo, L. E. A., Camarotte, G., Cannavan, F., Cardozo, J., Chambergo, F., Ciapina, L. P., Cicarelli, R. M. B., Coutinho, L. L., Cursino-Santos, J. R., El-Dorry, H., Faria, J. B., Ferreira, A. J. S., Ferreira, R. C. C., Ferro, M. I. T., Formighieri, E. F., Franco, M. C., Greggio, C. C., Gruber, A., Katsuyama, A. M., Kishi, L. T., Leite, R. P., Lemos, E. G. M., Lemos, M. V. F., Locali, E. C., Machado, M. A., Madeira, A. M. B. N., Martinez-Rossi, N. M., Martins, E. C., Meidanis, J., Menck, C. F. M., Miyaki, C. Y., Moon, D. H., Moreira, L. M., Novo, M. T. M., Okura, V. K., Oliveira, M. C., Oliveira, V. R., Pereira, H. A., Rossi, A., Sena, J. A. D., Silva, C., De Souza, R. F., Spinola, L. A. F., Takita, M. A., Tamura, R. E., Teixeira, E. C., Tezza, R. I. D., Trindade dos Santos, M., Truffi, D., Tsai, S. M., White, F. F., Setubal, J. C., and Kitajima, J. P. 2002. Comparison of the genomes of two Xanthomonas pathogens with differing host specificities. Nature 417:459-463.

20. Excoffier, L., Laval, G., and Schneider, S. 2005. Arlequin ver. 3.0: An integrated software package for population genetics data analysis. Evol. Bioinform. Online 1:47-50.

21. Gabriel, D. W., Kingsley, M. T., Hunter, J. E., and Gottwald, T. R. 1989. Reinstatement of Xanthomonas citri (ex Hasse) and X. phaseoli (ex Smith) and reclassification of all $X$. campestris pv. citri strains. Int. J. Syst. Bacteriol. 39:14-22.

22. Gascuel, O. 1997. Concerning the NJ algorithm and its unweighted version UNJ. B. Mirkin, F. R. Mcmorris, F. S. Roberts, and A. Rzhetsky, eds. Mathematical Hierarchies and Biology. American Mathematical Society, Providence, RI. 37:149-171.

23. Gottwald, T. R., Graham, J. H., Civerolo, E. L., Barrett, H. C., and Hearn, C. J. 1993. Differential host range reaction of citrus and citrus relatives to citrus canker and citrus bacterial spot determined by leaf mesophyll susceptibility. Plant Dis. 77:1004-1009.

24. Gottwald, T. R., Hughes, G., Graham, J. H., Sun, X., and Riley, T. 2001. The citrus canker epidemic in Florida: The scientific basis of regulatory eradication policy for an invasive species. Phytopathology 91:30-34.

25. Gottwald, T. R., Sun, X., Riley, T., Graham, J. H., Ferrandino, F., and Taylor, E. L. 2002. Geo-referenced spatiotemporal analysis of the urban citrus canker epidemic in Florida. Phytopathology 92:361-377.

26. Graham, J. H., Gottwald, T. R., Cubero, J., and Achor, D. S. 2004. Xanthomonas axonopodis pv. citri: Factors affecting successful eradication of citrus canker. Mol. Plant Pathol. 5:1-15.

27. Grant, S. R., Fisher, E. J., Chang, J. H., Mole, B. M., and Dangl., J. L. 2006. Subterfuge and manipulation: Type III effector proteins of phytopathogenic bacteria. Annu. Rev. Microbiol. 60:425-449.

28. Jaciani, F. J., Destéfano, S. A. L., Rodrigues Neto, J., and Belasque, J., Jr. 2009. Detection of a new bacterium related to Xanthomonas fuscans subsp. aurantifolii infecting Swingle citrumelo in Brazil. Plant Dis. 93:1074.

29. Kalinowski, S. T. 2004. Counting alleles with rarefaction: private alleles and hierarchical sampling designs. Conserv. Genet. 5:539-543.

30. Kalinowski, S. T. 2005. HP-RARE 1.0: A computer program for performing rarefaction on measures of allelic richness. Mol. Ecol. Notes 5:187-189.

31. Karen-Beth, G. S., Herman, B. S., and Andrew, O. J. 1993. Control of plant virus diseases by pathogen-derived resistance in transgenic plants. Plant Physiol. 102:7-12.

32. Kendall, M. G., and Babington-Smith, B. 1939. The problem of m rankings.
Ann. Math. Stat. 10:275-287.

33. Leach, J. E., and White, F. F. 1996. Bacterial avirulence genes. Annu. Rev. Phytopathol. 34:153-179.

34. Li, W., Song, Q., Brlansky, R. H., and Hartung, J. S. 2007. Genetic diversity of citrus bacterial canker pathogens preserved in herbarium specimens. Proc. Natl. Acad. Sci. 104:18427-18432.

35. Louws, F. J., Fulbright, D. W., Stephens, C. T., and Brujin, F. J. 1994. Specific genomic fingerprints of phytopathogenic Xanthomonas and Pseudomonas pathovars and strains generated with repetitive sequences and PCR. Appl. Environ. Microbiol. 60:2286-2295.

36. Nimchuk, Z. L., Fisher, E. J., Desveaux, D., Chang, J. H., and Dangl, J. L. 2007. The Hop X (AvrPphE) family of Pseudomonas syringae Type III effectors require a catalytic triad and a novel $\mathrm{N}$-terminal domain for function. Mol. Plant-Microbe Interact. 20:346-357.

37. Ochiai, H., Horino, O., Miyajima, K., and Kaku, H. 2000. Genetic diversity of Xanthomonas oryzae pv. oryzae strains from Sri Lanka. Phytopathology 90:415-421.

38. Pavan, A., Calixto, M. C., Cardoso, S. C., Mendes, B. M. J., Bergamin Filho, A., Lopes, J. R. S., Carvalho, C. R., and Mourão Filho, F. A. A. 2007. Evaluation of 'Hamlin' sweet orange + 'Montenegrina' mandarin somatic hybrid for tolerance to Xanthomonas axonopodis pv. citri and Xylella fastidiosa. Sci. Hortic. 113:278-285.

39. Petes, T. D., and Hill, C. W. 1988. Recombination between repeated genes in microorganisms. Annu. Rev. Genet. 22:147-168.

40. Restrepo, S., Vélez, C. M., and Verdier, V. 2000. Measuring the genetic diversity of Xanthomonas axonopodis pv. manihotis within different fields in Colombia. Phytopathology 90:683-690.

41. Schaad, N. W., Postnikova, E., Lacy, G. H., Sechler, A., Agarkova, I., Stromberg, P. E., Stromberg, V. K., and Vidaver, A. K. 2005. Reclassification of Xanthomonas campestris pv. citri (ex Hasse) Dye 1978 forms A, $\mathrm{B} / \mathrm{C} / \mathrm{D}$, and $\mathrm{E}$ as $X$. smithii subsp. citri (ex Hasse) sp. nov. nom. rev. comb. nov., X. fuscans subsp. aurantifolii (ex Gabriel 1989) sp. nov. nom. rev. comb. nov., and X. alfalfae subsp. citrumelo (ex Riker and Jones) Gabriel $e t$ al., 1989 sp. nov. nom. rev. comb. nov.; X. campestris pv. malvacearum (ex Smith 1901) Dye 1978 as X. smithii subsp. smithii nov. comb. nov. nom. nov.; X. campestris pv. alfalfae (ex Riker et al., 1935) sp. nov. nom. rev.; and "var. fuscans" of X. campestris pv. phaseoli (ex Smith, 1987) Dye 1978 as X. fuscans subsp. fuscans sp. nov.. Syst. Appl. Microbiol. 28:494-518.

42. Schaad, N. W., Postnikova, E., Lacy, G. H., Sechler, A., Agarkova, I., Stromberg, P. E., Stromberg, V. K., and Vidaver, A. K. 2006. Emended classification of xanthomonad pathogens on citrus. Syst. Appl. Microbiol. 29:690-695.

43. Sun, X., Stall, R. E., Jones, J. B., Cubero, J., Gottwald, T. R., Graham, J. H., Dixon, W. D., Schubert, T. S., Chaloux, P. H., Stromberg, V. K., Lacy, G. H., and Sutton, B. D. 2004. Detection and characterization of a new strain of citrus canker bacteria from key/Mexican lime and alemow in South Florida. Plant Dis. 88:1179-1188.

44. Swarup, S., Feyter, R., Brlansky, R. H., and Gabriel, D. W. 1991. A pathogenicity locus from Xanthomonas citri enables strains from several pathovars of $X$. campestris to elicit canker like lesions on citrus. Phytopathology 81:802-809.

45. Vauterin, L., Hoste, B., Kersters, K., and Swings, J. 1995. Reclassification of Xanthomonas. Int. J. Syst. Bacteriol. 45:472-489.

46. Vauterin, L., Rademaker, J., and Swings, J. 2000. Synopsis on the taxonomy of the genus Xanthomonas. Phytopathology 90:677-682.

47. Verdier, V., Restrepo, S., Mosquera, G., Duque, M. C., Gerstl, A., and Laberry, R. 1998. Genetic and pathogenic variation of Xanthomonas axonopodis pv. manihotis in Venezuela. Plant Pathol. 47:601-608.

48. Vernière, C., Hartung, J. S., Pruvost, O., Civerolo, E. L., Alvarez, A. M., Maestri, P., and Luisetti, J. 1998. Characterization of phenotypically distinct strains of Xanthomonas axonopodis pv. citri from Southwest Asia. Eur. J. Plant Pathol. 104:477-487.

49. Yang, L., Hu, C., Li, N., Zhang, J., Yan, J., and Deng, Z. 2011. Plant Mol. Biol. 75:11-23. 